\title{
Az Eurázsia-narratíva kibontakozásának vizsgálata a magyar kormányzati nyilatkozatok és fejlesztéspolitikai dokumentumok tükrében ${ }^{1}$
}

\author{
Examining the Evolution of the Eurasian Narrative in Hungary \\ in the Light of Government Statements \\ and Development Policy Documents
}

Salamin Géza, Megyesi Zoltán és Klemensits Péter https://doi.org/10.47707/Kulugvi Szemle.2021.3.6

Összefoglaló: A magyar kormányzat a 2008-as gazdasági válság hatásaira, valamint a világgazdaság súlypontjának keletre vándorlására tekintettel a keleti nyitás politikája mellett kötelezte el magát, azaz a keleti feltörekvő piacok felé irányuló export növelését, ezáltal a kivitel diverzifikálását célozta meg. A 2010 óta stabilan kormányzó politikai erő részéről a külgazdasági koncepció mellett az elmúlt tíz évben egy Eurázsia köré épülő geopolitikai narratíva is kikristályosodott. A tanulmány a Gearóid Ó Tuathail által megfogalmazott gyakorlati geopolitikai érvelési modell alkalmazásával, a kormányzati szereplők beszédei, interjúi és esemény-összefoglalói, illetve a fejlesztéspolitika tervdokumentumai alapján igyekszik beazonosítani és értékelni a magyar Eurázsia-narratívát, továbbá bemutatni az annak megvalósítására tett legfontosabb lépéseket és azok külső feltételrendszerét.

Kulcsszavak: Eurázsia, geoökonómia, geopolitika, politikai földrajz, nemzet közi kapcsolatok, fejlesztéspolitika

Abstract: Taking into account the effects of the economic crisis of 2008 and adapting to the shift of the world economy's centre of gravity to the east. the Hungarian government commitled itself to the Opening Toward East Policy, i.e.. to increase exports to the eastern emerging markets and thus diversify exports. The geopolitical narrative built around Eurasia over the past ten years has also crystallised in the foreign economic concept by the political force that has been stable since 2010. Using the practical geopolitical reasoning model formulated by

1 A kézirat lezárásának ideje: 2021. március. 
Gearóid Ó Tuathail, the study attempts to identify and evaluate the Hungarian Eurasian narrative based on the speeches, interviews, and documents of planning policy, as well as to present the most important steps and external conditions.

Keywords: Hungary, Eurasia narrative, practical geopolitical reasoning, foreign policy, development policy, geopolitics, political geography

\section{Bevezetés}

Az utóbbi években - a geopolitikai szakértők következtetéseivel, prognózisaival összhangban - több nagyhatalom kormányzata is nyíltan felvállalta Eurázsiának mint politikai és gazdasági entitásnak a megteremtését (lásd pl. Frankopan, 2018; Maçães, 2018; Calder, 2019). A legismertebb ezek közül talán Kína Egy Övezet Egy Út (One Belt One Road, OBOR; mai nevén: Övezet és Út Kezdeményezés, Belt and Road Initiative, BRI) projektje, de ebbe a sorba illik Oroszországnak az Eurázsiai Unióról szóló terve is. Ugyanakkor az Európai Unió, India, továbbá az olyan kisebb államok, mint Magyarország Eurázsia-narratívái is figyelmet érdemelnek.

Magyarország a makroregionális földrajzi helyzetét tekintve Közép-Európában, még pontosabban Kelet-Közép-Európában található, ám azt gyakran összemossák Kelet-Európával. A kategorizálási különbségek közötti távolságot a tartalmában és jelenté sében is vitatott fogalmú Köztes-Európa kifejezés hidalhatja át. Köztes-Európát a legegyszerúbben úgy lehet behatárolni, hogy az a Nyugat-és Kelet-Európa közötti átmeneti térség, amely Finnor szágtól Görögországig húzódik, s magában foglalja a német és az orosz államtér között fekvő kisállamokat, valamint Lengyelországot és Ukrajnát. Az első világháború óta a kontinens fő konflik tus-és ütközőzónájaként jelent - és jelenik - meg Kelet és Nyugat között (Nagy, 2014, 32. o.). E hagyományos szerepkör a Krím félsziget orosz annektálása következtében ismét felerősödött. A világpolitikai hatalmi egyensúly azonban átalakulóban van. Az Amerikai Egyesült Államok vezető szerepének megtartása mellett Eurázsiában új hatalmi központként jelent meg az ismét aktív Oroszország és a gyor san fejlődő Kína. Ebből a szempontból Köztes-Európa - észak-déli 


\section{Külïgyi Szemle}

középpontjában Magyarországgal - a földrajzi helyzetéből adódóan a geopolitikai pufferzóna szerepkörből a feltörekvő Keletet és a fejlett Nyugatot összekötő hídtérséggé léphet elő (Bernek, 2018b, 105. o).

A tanulmány a magyar Eurázsia-narratíva bemutatására vállalkozik, amelyhez az elméleti keretet Gearóid Ó Tuathail „Theorizing Practical Geopolitical Reasoning: the Case of the United States' Response to the War in Bosnia” címú, a Political Geography 2002. évi 5. számában megjelent tanulmánya (Ó Tuathail, 2002) szolgáltatja. Az ír szerző az írásában az Egyesült Államoknak a boszniai háborúval kapcsolatos geopolitikai narratíváját vizsgálta, amelynek során az ún. gyakorlati geopolitikai érvelési modellben egy négy részből álló módszertani megközelítést vázolt fel a külpolitikai elitek érvelésének elemzéséhez. Ezek:

- a külpolitikai probléma meghatározása (annak tisztázása, hogy mi tekinthetô egy politikai kihívás részének, hogyan definiálható az adott probléma, és milyen jelentőséggel bír az állam/ nemzet számára);

- a „geopolitikai stratégia” meghatározása (amely alapvetően a befolyással bíró szereplők magas szintű egyeztetésein történik);

- a stratégia további „finomhangolása” (amelynek során a dön téshozók megkísérlik az érintett felek érdekeit, félelmeit és po litikai szükségleteit összeegyeztetni);

- a probléma „lezárása”, azaz a megfogalmazott probléma megoldása és az annak érdekében tett konkrét politikai lépések (ez nem minden esetben jelent valódi megoldást, gyakran csak halasztást - annak reményében, hogy a probléma idővel érdemi beavatkozás nélkül is veszíteni fog a jelentőségéből) (Ó Tuathail, 2002, 622. o.).

A geopolitikai narratíva rendeltetése lényegében az, hogy világos és látható módon olyan érveket fogalmazzon meg, amelyek a nemzet nagyobb részének a mozgósítását serkentik. A kritikai geopolitika valódi jelentősége, hogy a külpolitika formálása során az egyes államok 
beazonosítható képességei mellett a humántényezőknek is meghatá rozó szerepet tulajdonít.

A tanulmány, alkalmazkodva az Ó Tuathail által megfogalmazott négyrészes elméleti kerethez, a keleti nyitással kapcsolatos magyar kormányzati nyilatkozatok elemzése és a fejlesztéspolitikai stratégiák tartalomelemzése alapján igyekszik beazonosítani és értékelni a magyar Eurázsia-narratívát, továbbá áttekinti az annak megvalósítására tett legfontosabb lépéseket és azok küilső feltételrendszerét.

\section{Eurázsia geopolitikai jelentősége}

Természetföldrajzi megközelítésben Eurázsia alatt az Európa és Ázsia által alkotott szuperkontinenst értjüik, amely geológiailag egyetlen földrésznek minősül. A politikai, gazdasági és kulturális heterogenitása ellenére a geopolitikában Eurázsia fogalma a kezdetektől komoly jelentőséggel bírt, amely a 20. században már az egyes nagyhatalmak geostratégiáját is alapvető mértékben befolyásolta. A 2000-es évektől a régió jelentősége ezen túlmenően is megnövekedett, ezért be szélhetünk attól kezdve egy eurázsiai korszak kialakulásáról, amelynek során a gazdasági, politikai, katonai hatalom egyre inkább Kelet felé tolódik, miközben az Atlanti-óceán térsége veszithet a központi súlyából. Ahogy a népszerű geopolitikai szakértő, Parag Khanna vélekedett erről: a világ ázsiaivá válik (Khanna, 2019, 36. o.). Ezzel párhuzamosan egy új, többközpontú világrend van kialakulóban, ahol a konnektivitás és a komplexitás révén Európa és Ázsia egysége új értelmet nyer, a 21. század pedig Eurázsia évszázada lehet.

Peter Frankopan a 2013-ban Kína által meghirdetett Övezet és Út Kezdeményezést vizsgálva már az eurázsiai szuperkontinens kialakulásáról írt (Frankopan, 2018, 266. o.). Bruno Maçães szerint pedig egy új világtérkép létrejöttének vagyunk a tanúi, amelynek során kialakul a Lisszabontól Jakartáig terjedő új földrajzi entitás, Eurázsia. A szuperkontinens erőközpontjai közül Kína tölti be a legfontosabb szerepet, hiszen a BRI részeként megvalósuló szárazföldi és tengeri szállítási folyosók révén az ország egy új globális gazdasági rendszer létrehozásán 


\section{Külïgyi Szemle}

munkálkodik, amelynek Peking lenne a központja (Maçães, 2018, 235. o.). ${ }^{2}$ Kent E. Calder is úgy látja, hogy a hidegháború óta a gazdasági növekedés központja Kelet-Ázsiába helyeződött át, Európa és Ázsia újrakapcsolódása pedig egy új szuperkontinens születését vetíti előre, amely az európai-kínai partnerségen alapszik (Calder, 2019, 71-85. o.). Eurázsia felemelkedése a nagyhatalmak és a kisebb országok számára egyaránt tartogat lehetőségeket és kihívásokat, ezért a fogalom geo politikai nézőpontból történő vizsgálata aktuálisabb, mint valaha, hi szen az új világrendnek - és benne hazánk nemzetstratégiájának, küil politikájának - a megismerése mindannyiunk számára közös érdek.

\section{Magyarország, \\ a kisállam történelmi megpróbáltatásai}

Az első világháborúban vesztes Magyarország külpolitikai mozgás tere az 1920-as évektől nagymértékben beszúküilt (Benyhe, 2018). Az ország képtelen volt elkerülni, hogy a második világháborúba belesodródva előbb a náci Németország, majd a világégést követően a Szovjetunió érdekszférájába kerüljön, külpolitikai szabadságát voltaképpen elveszítve szatellitállammá váljon.

1945 után Magyarország több mint negyven évre a hidegháborús szembenállás bipoláris világrendjének keleti, szocialista blokkjába ke rült. Az 1956-os forradalmat követő - a fokozatosan puha diktatúrába átmenő - Kádár-rendszer az életszínvonal emelésével kísérelte meg legitimálni önmagát, azonban a szocialista gazdasági rendszer rugalmatlanságai miatt az 1973-as olajárrobbanás után annak folytatása jórészt már csak külső, főleg nyugati forrásokból, hitelekből volt finanszírozható, ami az ország fokozatos eladósodásához és a pénzügyi csődközeli állapothoz vezetett (Bod, 2019, 19. o.).

A rendszerváltással párhuzamosan megváltozott a nemzetközi kör nyezet is: a Szovjetunió összeomlásával elveszítette a bipoláris jellegét; a szocialista rendszer bukása a nyugati liberális demokráciák győzelmét

2 A BRI geopolitikai jelentőségéről európai nézőpontból ld. Kocsis, Komjáthy és Péti, 2017, 37-63. o. 
hozta, globálisan kiteljesedett a Pax Americana. Kis és gazdaságilag nyitott országként hazánk számára más érdemi lehetőség hiányában egyértelmű volt, hogy csatlakoznia kell az Európai Közösséghez.

Természetesen a szocializmusból a nyugati mintájú piacgazdaságra való áttérés számos nehézséggel és társadalmi megrázkódtatással járt. A radikális átállás jegyében Magyarország a rendszerváltozás első három évében elvesztette a nemzeti terméke 20 százalékát (Bod, 1995), a GDP 18 százalékkal, a foglalkoztatottak száma pedig mintegy másfél millióval csökkent (Központi Statisztikai Hivatal, 2010, 30. o.). A transzformációs visszaesést és recessziót követően 1997-től indult meg a magyar gazdaság európai konvergenciája. A külkereskedelemben áthelyeződtek a súlypontok: az Európai Unió lett Magyarország fő kereskedelmi partnere, és a tőkeberuházások többsége is Nyugat-Európából érkezett. Az ország az Európai Unió gazdaságával való szoros egybefonódása eredményeként többnyire az európai és a világgazdasági konjunktúraciklusokat követve fejlődött, kiegyenlített, átlagosan 4 százalék körüli éves gazdasági növekedéssel (Központi Statisztikai Hivatal, 2010, 31. o.).

A gazdasági felzárkózással párhuzamosan azonban 2002-től a háztartások és az állam meredek - ráadásul küllföldi devizában történő - eladósodása kezdődött meg, így a konvergencia végüil az eladósodás fenntarthatatlansága és az azt kiegyensúlyozni kívánó kormányzati intézkedések folytán meg is akadt (Oblath, 2014, 21. o.). A 2008-as gazdasági válság begyűrűzése már olyan strukturális egyensúlytalanság közepette érte az országot, amely végüil az IMF-hitel felvételéhez vezetett (Miklós, 2013, 83. o.).

A nemzetközi kapcsolatok mellett az európai gazdasági térben sem sikerült - Kelet-Közép-Európa egészével együtt - Magyarországnak számottevően javítania a geoökonómiai helyzetét. A 2000 és 2012 közötti periódus makroregionális folyamatait vizsgáló gazdaságföldrajzi elemzés tanúsága szerint (Salamin, 2015, 73-91. o.) Európán belül rögzülttek a centrum-periféria-viszonyok, amelyeket többféle, a magterületekhez kapcsoló függés (FDI, EU-források, munkaerőpiaci elszivás) tart fenn, illetve erősít. A mérsékelt gazdasági konvergencia 


\section{Külïgyi Szemle}

ellenére továbbra is a kelet-nyugati dichotómia a legerősebb dimen ziója az európai tér tagolódásának.

Összességében Magyarország európai konvergenciájának az első két évtizede (1990-től) azzal jellemezhető, hogy a kezdeti lehetőségeihez és a mérvadó összehasonlítást jelentő országokhoz mérten egyaránt alulteljesített (Oblath, 2014, 48. o.). 2010-tôl azonban a fis kális reformok, majd 2013-tól a monetáris politikai fordulat ismét felzárkózási pályára állította a magyar gazdaságot. Az ország fejlettsége az egyensúlyi helyzet megtartása mellett folyamatosan közeledett a nyugat-európai államok szintjéhez (Magyar Nemzeli Bank, 2018, 7. o.), egyes években pedig az Európai Unió legnagyobb növekedési ütemét mutató országai között volt.

\section{A keleti nyitás politikája: az Eurázsia-gondolat megjelenése a kommunikációban}

A gazdasági válságot követően a 2010-ben megválasztott Orbán-kormány a rendszerváltás óta kizárólagos nyugati társadalmi-gazdasági modell és kapcsolatok mellett egy új gazdaságpolitikai irányvonalat, valamint a küllkapcsolatok és a küilgazdaság diverzifikációját jelölte meg a magyar gazdaság ismételt növekedési pályára állításának eszközeként. A külpolitikai nyitás tervezett fő iránya a keleti, feltörekvő országok jelentették (Magyarország Kormánya, 2012, 190. o.), ami a gyakorlatban a keleti nyitás politikája néven vált ismertté. E köré épülve a magyar kormányzat részéról új geopolitikai narratíva kristályosodott ki az elmúlt közel egy évtized során, amelyet jól összegez a miniszterelnök alábbi megnyilatkozása:

„A mi fülüinknek furcsán hangzik még a kifejezés, de itt Eurázsia építésérôl beszélüink. Három koncepció is asztalon van mindig, amikor Európa jövőjéről beszélüink, az eurázsiai, az euramerikai és euarábiai koncepciók. Ezeknek mindegyikében sok igazság van, de kétségkívïl gazdaságilag az újszerú és leginkább vonzó az eurázsiai megközelítés." (Miniszlerelnök.hu, 2018) 
Miért jutott Magyarország miniszterelnöke erre a megállapításra? Mi az a terület, melyek azok az országok, amelyeket magában foglal Eurázsia? Hogyan zajlik a gyakorlatban Eurázsia építése? A kérdések megválaszolásához és az Eurázsia-narratíva alakulásának analitikusabb elemzéséhez módszertanilag a magyar kormányzati szereplők megnyilvánulásainak tartalomelemzése nyújt segítséget. A forrásukat a magyar kormány és a miniszterelnök hivatalos weboldalán ( $M a-$ syarország Kormánya; Miniszterelnök.hu) található azon beszédek, interjúk és esemény-összefoglalók jelentik, amelyekben szerepelt az Eurázsia és az eurázsiai kulcsszó. A keresés a 2014 októberétól 2020 júniusáig terjedő időszakban 58 találatot jelzett. A szövegek alapján a magyar kormányzat eurázsiai alapú geopolitikai érvelése az alábbiakban olvasható.

A 2010-es évtizedre alapvető változások indultak meg a nemzet közi rendben és az erôviszonyok alakulásában. Az euroatlanti, azaz a nyugati országok 2008-as válsága óta, valamint a keleti államok gyors gazdasági fejlődése következtében a világ gazdasági centruma egyre inkább a csendes-óceáni térre tevődik át. Ezt támasztotta alá az a tény is, hogy a 2009-ben hatalomra került Barack Obama első elnök ségi ciklusában viszonylag leértékelődtek az Amerikai Egyesült Államok számára az atlanti kapcsolatok, és az európai kontinens egyre inkább háttérbe szorult az amerikai geopolitikai stratégiák terén (egészen a krími válságig). Ezzel kapcsolatban a kelet-közép-európai or szágok csalódása még a vezető európaiakénál is nagyobb volt (Bernek, 2018b, 62. o.). Mindezek alapján azzal a hipotézissel élhetünk, hogy az Orbán-kormányzat azt a következtetést vonta le, hogy Magyarország nemzetközi környezetében alapvető átrendeződés indult meg, ezért a rendszerváltás óta jóformán kizárólagos atlanti centrikus geopolitikai narratíván változtatni szüikséges, és hazánk stratégiai érdeke, hogy Kelet felé is nyisson.

A motivációk közüil a külpolitikai környezet változása mellett Ma gyarország esetében szüikséges a belső társadalmi-gazdasági ténye zóket is megjelölni. Egyrészt a 2000-es évek második felének gaz dasági és pénzügyi válsága következtében a rendszerváltási folyamat 


\section{Külïgyi Szemle}

során már-már kritikátlanul átvett neoliberális nyugati gazdasági minta és orientáció konvergenciavárakozásai a társadalom széles rétegei számára beteljesületlenek maradtak, s ez elfogadhatóbbá tette a külpolitikai preferenciák részleges keletre tolódását (Bod, 2019, 35. o.). Másrészt a magyar identitásban alapvetően jelen vannak a keleti orientáció jegyei. A magyarság őstörténetére és származására építve sajátos irányvonalat képvisel az úgynevezett turanizmus, amely a Iuráni (török, altaji) népekkel való kapesolatokra fókuszál. Az elsősorban földrajztudományi, majd nyelvészeti és kulturális indíttatású eszmerendszer már a két világháború között is politikai tartalommal is bírt (Bernek, 2018b, 33. o.).

Az elemzett szövegek alapján a felmerüilt problémákra választ kínáló magyar Eurázsia-narratíva geopolitikai stratégiájának a gerince a Kelet és Nyugat közötti együttmúködés megindítása köré épül. Ez az 58 talált szövegből 36-ban, azaz jóval több mint a felében jelenik meg. A narratíva szerint a 2008 -as válságot követő korszakváltás és a születőben lévő új világrend következtében a korábbi hidegháborús logikát Nyugat-Európának és az Európai Uniónak maga mögött kell hagynia, és egy eurázsiai léptékű együttműködésre van szükség ahhoz, hogy Európa ismét versenyképes legyen, s elkerülhetővé váljon egy, a 2008-ashoz hasonló válság.

Kelet és Nyugat kooperációja a BRI-nek mint konkrét eurázsiai gazdasági koncepciónak a megjelenésével egy, az egész térségre kiterjedő kapcsolatban öltött egyre inkább testet. Az Eurázsia mint egységes gazdasági térség és piac említése a kínai kezdeményezés előrehaladtával párhuzamosan egyre gyakoribb. (1. ábra). E narratívában mintegy mellékesen megjelenik, hogy az együttmúködést pragmatikusan, ideológiamentesen és a belpolitikai kérdések figyelmen kívül hagyásával kell megvalósítani, azaz tiszteletben kell tartani, hogy a keleti rendszerek alapvetően más politikai berendezkedésűek. Mindezzel kapcsolatban a narratíva Magyarország közvetítő szerepét hangsúlyozza, mind földrajzi, mind kulturális értelemben: Magyarország kapu, hidtérség a kelet-nyugati viszonyban, üzletelés helyett valódi keleti nyitásra törekszik. 


\section{1. ábra ${ }^{3}$}

A Magyarország Eurázsia-narratívájában megjelenő fỏbb tartalmak 2015 és 2019 között (csak telies évek)

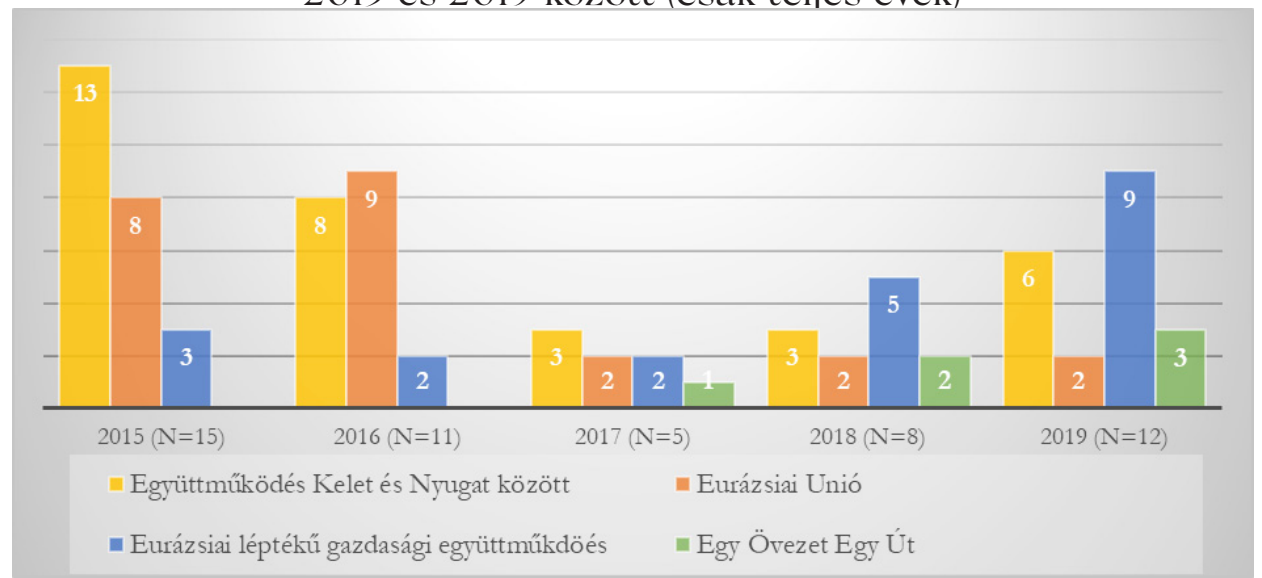

Ez a keleti irányba kialakítandó együttmúködés és Eurázsia pon tos földrajzi helyzete a narratívában olykor kevésbé definiált, több alkalommal ország, országcsoport meghatározása nélkül, egyszerủen eurázsiai térséget említenek, vagy az igen tág földrajzi keretet felölelő Lisszabontól Vlagyivoszlokig tartó övezet kerül szóba. A konkrét földrajzi tartalommal bíró hivatkozások közül a vizsgált időszak végéig az Eurázsiai Gazdasági Unió fordul elő a legtöbbször, amely különösen a megalakulása és a krími válság következtében elhidegült nyugatiorosz viszonyban uralta a narratívát. Ezért a nevesített országok közül Oroszország jelenik meg a legtöbbször. Általánosan kijelenthető, hogy a magyar Eurázsia-narratíva elsősorban a posztszovjet térségre utal (2. ábra). Ezt az utóbbi két évben némileg ellensúlyozza az Övezet és Út Kezdeményezés megindítása óta mind gyakrabban szereplő Kína.

3 Forrás: a Magyarország Kormánya és a Miniszlerelnök.hu honlapon található beszédek, interjúk és esemény-összefoglalók alapján saját szerkesztés. 


\section{Külïgyi Szemle}

2. ábra ${ }^{4}$

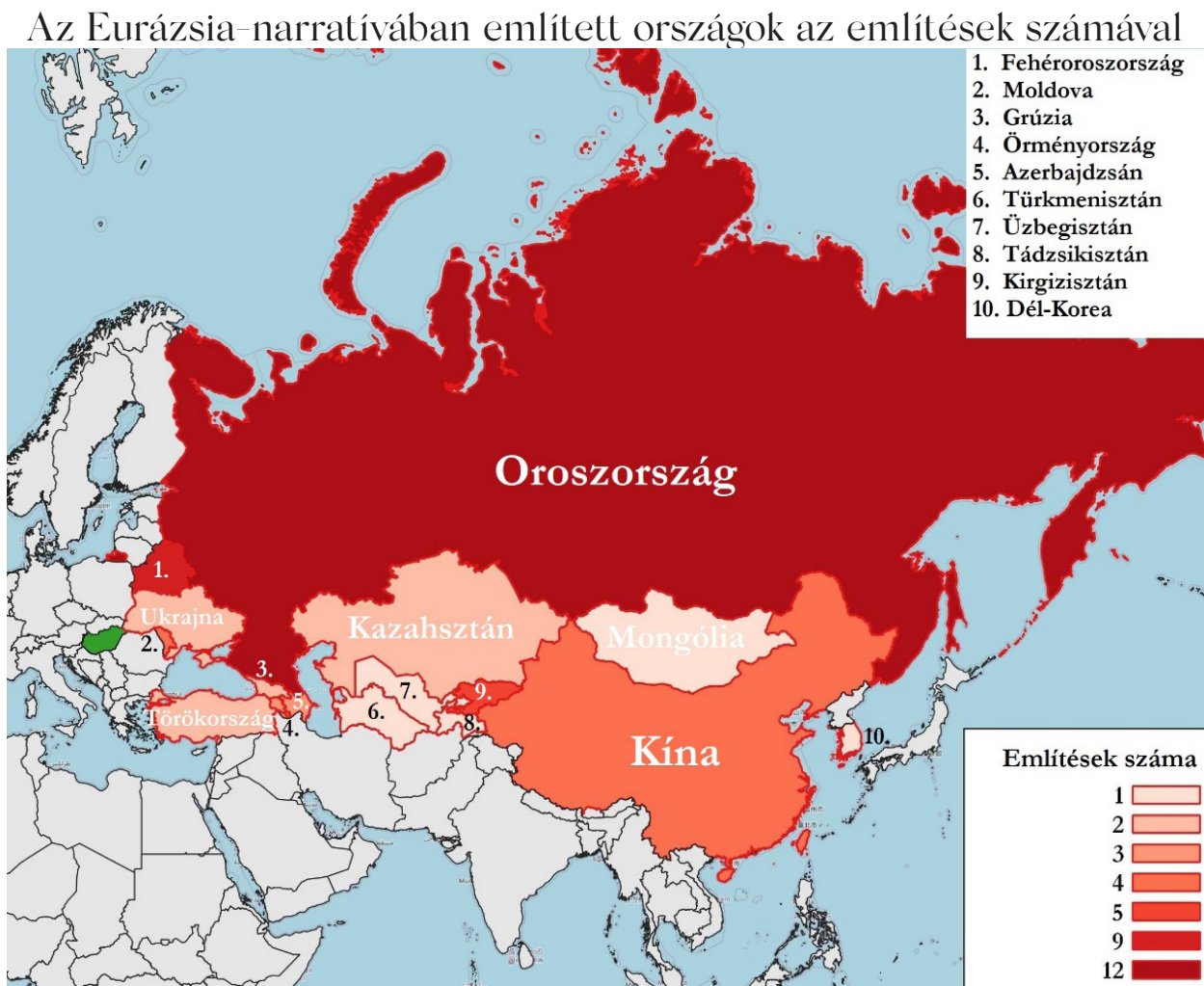

\section{A keleti nyitás és az Övezet és Út Kezdeményezés megjelenése a fejlesztéspolitikai stratégiákban}

A keleti nyitás narratívája a politikai nyilatkozatok és diskurzus mellett a szakpolitikai szándékokat megfogalmazó stratégiákban, tervekben is tetten érhető. E fejezetben a beruházások vezérléséhez kapcsolódó fejlesztéspolitikai dokumentumok tartalma alapján, valamint a koráb bi vizsgálatunk eredményei felhasználásával értékeljük a keleti nyitás elsődleges területét jelentő, Új Selyemútként is emlegetett Övezet és

4 Forrás: a Magyarország Kormánya és a Miniszlerelnök.hu található beszédek, interjúk és esemény-összefoglalók alapján saját szerkesztés. 
Út Kezdeményezés megjelenését és lehetőségeit (Kocsis, Komjáthy, Péti és Salamin, 2017, 249-283. o.).

Értelmezésünkben a fejlesztéspolitika a szakpolitikák azon közös - és olykor egységes stratégiába fogott - halmaza, amely közvetlenül a közfejlesztési beruházási erőforrásokra irányul (Vö. Péti, 2010; Péti, Botka, Szilágyi, Salamin és Radvánszki, 2009), s mint ilyen, a kormányzati politikának - vagy éppen az EU politikai céljainak - fontos eszköze. A jelentősebb hagyományokkal rendelkező, jobban intézmé nyesült szakpolitikák - mint pl. a terület-, gazdaság-, közlekedésfejlesztés - fejlesztéspolitikai megjelenése eróteljesebb, és a küiönböző stratégiai dokumentumokban is jobban megnyilvánul. A Magyarországon viszonylag újnak tekinthető kormányzati geopolitika ilyen jellegű szakpolitikai beágyazódással ma még nem rendelkezik, ezért a fejlesz tésorientált szakpolitikai stratégiákban való megjelenésének lehetősé ge is újszerú felvetés. Meg kell azonban említenünk, hogy a rendszer szerú fejlesztéspolitika geopolitikai eszközkénti alkalmazása mégsem előzmények nélküli hazánkban, hiszen a határon átívelő nemzetegye sítés nemzetstratégiai doktrínájának eszközeként már megjelent egyfajta Kárpát-medencei területi fejlesztéspolitika (Ld. Horkay, Péti és Sütő, 2015.), amelynek bizonyos elemei már a 2014-2020-as időszak kohéziós politikai forrásainak a hazai stratégiai keretét jelentő Partnerségi Megállapodás dokumentumában is megjelentek (Péti, 2014).

Magyarország rendszerváltozás utáni fejlesztéspolitikájában mindvégig az Európai Unió képezte a fó igazodási pontot, s ez a kilencvenes évek közepétől az előcsatlakozási támogatások megjelené se, majd a 2004-es csatlakozás után a kohéziós politika tagállami ke retei révén csak fokozódott. Mindeközben a hazai támogatáspolitika leépüilt, illetve az európai uniós törekvésekhez kapcsolódott. A kínai Övezet és Út Kezdeményezéssel egy Európán kívuilről kiinduló intéz ményesített fejlesztési rendszer hatása is megjelent, s Magyarország számára is számos téren jelentős változásokat hozhat.

Az elemzés elkészitése érdekében vizsgált, összesen 46 magyar nemzeti tervdokumentum közül tizenegyben fordult elő az Új Selyem úthoz részben kapcsolható fejlesztési tartalom, de a kezdeményezés nevesítve egyik dokumentumban sem szerepelt. 


\section{Külïgyi Szemle}

A következőkben röviden áttekintjüik, hogy milyen jelenlegi hazai helyzetértékelési vagy fejlesztési elképzelésekkel rokoníthatók a legin kább e távol-keleti kezdeményezés témakörei. Érthető módon a leg markánsabban Magyarország 2011-es Külgazdasági stratégiája (Nem zelgazdasági Miniszlérium, 2011) érinti a kérdést, amely tulajdonképpen a keleti nyitás szakpolitikai megfogalmazását is jelenti. E stratégia sze rint a kelet felé történő exportfejlesztés azért is fontos, hogy a kivitelüikön keresztül a magyar vállalkozások is egyre nagyobb arányban profitálhassanak a dinamikusan fejlődő gazdaságok (Kína, India és Oroszország) importnövekedéséből. E célból a stratégia Kína esetén az orvosi műszergyártást, az agráriumot, az élelmiszeripart, a kör nyezet- és vízipart, az alternatív energetikát, illetve bármely terület korszerú gyártási technológiáját tartja a legígéretesebb lehetőségnek.

A 2014-ben elfogadott - és jelenleg is hatályos - Országos fej lesztési és területfejlesztési koncepció (Magyar Közlöny, 2014) kül detése Magyarország fejlesztési céljainak és igényeinek az integrálá sa, továbbá azok területi dimenzióinak a meghatározása; a közvetlen funkciója a 2014-2020-as uniós tervezési és költségvetési időszak megalapozása volt. Az OFTK tartalma azért is különösen fontos a vizsgálat szempontjából, mert 2020-ig, illetve egy hosszabb távú kite kintéssel 2030-ig tartalmazza Magyarország fejlesztési célkitűzéseit. A koncepció „Helyünk a világtérképen: üitközőterületből közép-euró pai találkozóhely" című alfejezete szerint a világ változási folyamata ihoz igazodva kell az ország geopolitikai preferenciáit meghatározni. A megfogalmazott geopolitikai jövőkép tehát a földrajzi adottságainkból eredő találkozóhelyi szerepkör megerősítése. A tervdokumentum értékelése szerint hazánk a jelenlegi pufferzónahelyzetéből Európa részeként világgazdasági és európai szinten is értelmezhető középeurópai gazdasági, kereskedelmi, közlekedési és innovációs hálózati központtá válhatna. Továbbá Nyugat-Európa innovációs zónájának a keleti, az ázsiai gazdasági erôtér felé nyíló kapujaként funkcionálhat na. A dokumentum szerint ennek megfelelően különösen a szolgálta tások, a logisztika és az innováció terén megkerüilhetetlen a közép európai üzleti kaputérség létrehozása. 
A Kárpát-medencei térség országainak a mélyebb gazdasági integrációját célzó Wekerle-terv (Nemzelgazdasági Miniszlérium, 2012) kiemeli, hogy a világgazdasági válságot követően Európában a gazdasági növekedés súlypontja nyugatról Közép-Európára tevődött át, s így a térség számára lehetővé válik, hogy az innováció vezérelt Észak nyugat-Európa és a munkaalapon dinamikusan fejlődő ázsiai térség találkozási pontjává váljon.

A Nemzeti közlekedési infrastruktúra-fejlesztési stratégia (Nem zeti Fejlesztési Minisztérium, 2014) azt hangsúlyozza, hogy az európai és a - kikötőkön keresztül elérhető - távolabbi gazdasági térségek fejlődése a magyarországi áruszállítás jelentős fejlődésének ígéreté vel kecsegtet - elsősorban az ország előnyös földrajzi elhelyezkedése és az abból fakadó potenciális „összekötő kapocs” szerepe következtében. Kiemeli továbbá, hogy hazánk transzkontinentális léptékben az ázsiai áruforgalom tekintetében megkerülhetetlen közvetítő térsé geknek is a kapuját jelenti (17. o.).

A Nemzeti energiastratégia 2030 (Nemzeti Fejlesztési Miniszléri um, 2012) a fejlett világ energiafüggésérỏl szóló fejezetében külön al fejezetet szentel Kínának és Indiának a globális energiapiacon történt megjelenésének (110. o.). A stratégia szerint Magyarországnak, figye lembe véve az energiahordozók mennyiségét és a növekvő fogyasztási igényt, két lehetősége lesz. Az egyik egy folyamatosan élesedő nemzetközi konfliktusokkal terhelt jövő, a másik a globális tendenciáktól való függetlenedés. Ez utóbbi eléréséhez a dokumentum öt eszközt nevez meg: az energiatakarékosságot, a megújuló energiaforrások minél nagyobb arányban történő felhasználását, a biztonságos atomenergia alkalmazását, az európai energiapiacokhoz való csatlakozást és a kétpólusú mezőgazdaság kialakítását (13. o..).

A Nemzeti turizmusfejlesztési stratégia 2030 (Nemzetgazdasági Minisztérium, 2017) azt szorgalmazza, hogy Magyarország fektessen nagyobb hangsúlyt a keleti kapcsolatokra. A dokumentum szerint a turizmus terén a kínai és az egyéb délkelet-ázsiai küldő piacok felér tékelődésére kell figyelni.

5 Piacvezérelt átkapcsolási lehetőség a biomassza energetikai és élelmiszeripari hasznosítása között. 


\section{Külïgyi Szemle}

A Nemzeti vízstratégia a hazai tudást és kapacitásokat kamatoz tató ún. vízipari exportot ösztönözte (Belügyminiszlérium Vizügyi Fóigazgatóság, 2017. 131. o.), a 2013-as változatában pedig (Vidékfejleszlési Miniszlérium, 2013. 72. o.) kifejezetten Ázsia, azon belül többek között Kína és az arab világ irányába történő nyitást célozta meg.

Az országos és az ágazati szintû tervdokumentumokhoz képest a megyei és térségi (terüileti) tervekben mégjóval kevésbé jelenik meg az Új Selyemúthoz köthető helyzetértékelési vagy fejlesztési elképzelés. A 22 tervdokumentum elemzése során csupán a Budapest-Belgrád-vasút beruházása által leginkább érintett két határ menti megye, Csongrád és Bács-Kiskun fejlesztési dokumentumaiban volt utalás a BRI-re, ne vesítés nélküil.

Összességében elmondható, hogy az európai uniós és a magyar országi fejlesztéspolitikában az Övezet és Út Kezdeményezés egyfaj ta fordulópontot jelent, mivel ráirányította a figyelmet az euroatlanti térségen, a nyugati civilizációkon kívüili fejlesztési tényezők szerepére. Az Európán túlra való kitekintés kisebb jelentőséggel ugyan, de min dig is jelen volt az EU és tagállamai nemzetközi fejlesztési program jaiban, szomszédsági politikáiban. Az ottani térségek azonban nem merültek fel olyan szerepkörökre, ahonnan erőteljes elképzelések vagy akár fejlesztési források érkezhetnének.

Mára világossá vált, hogy Kína immár nem csupán egyre fontosabb üzleti-kereskedelmi partner, hanem egy tudatos fejlesztési és befektetési politikák révén közelítő szereplő. Pekingnek az e célra szánt gazdasági erőforrásai pedig bizony lassan megközelíthetik az Európán belüi újraelosztásra kerüilő fejlesztési közforrások nagyságrendjét is (Vö. Kocsis, Komjáthy, Péti és Salamin Géza, 2017, 271. o.). A BRI keretében tervezett konkrét projekt, a Budapest és Belgrád közötti vasút magyarországi szakaszának a kiépítése becslések sze rint 500 és 700 milliárd forint közti összegbe kerülne, és a beru házás több mint 80 százalékban kínai devizahitelből valósulna meg (Matura, 2016. 36. o.). 


\section{3. ábra ${ }^{6}$}

A Budapest-Belgrád-vasút magyarországi szakaszának becsült beruházási költsége néhány fontos gazdasági adattal összevetve (milliárd Ft)

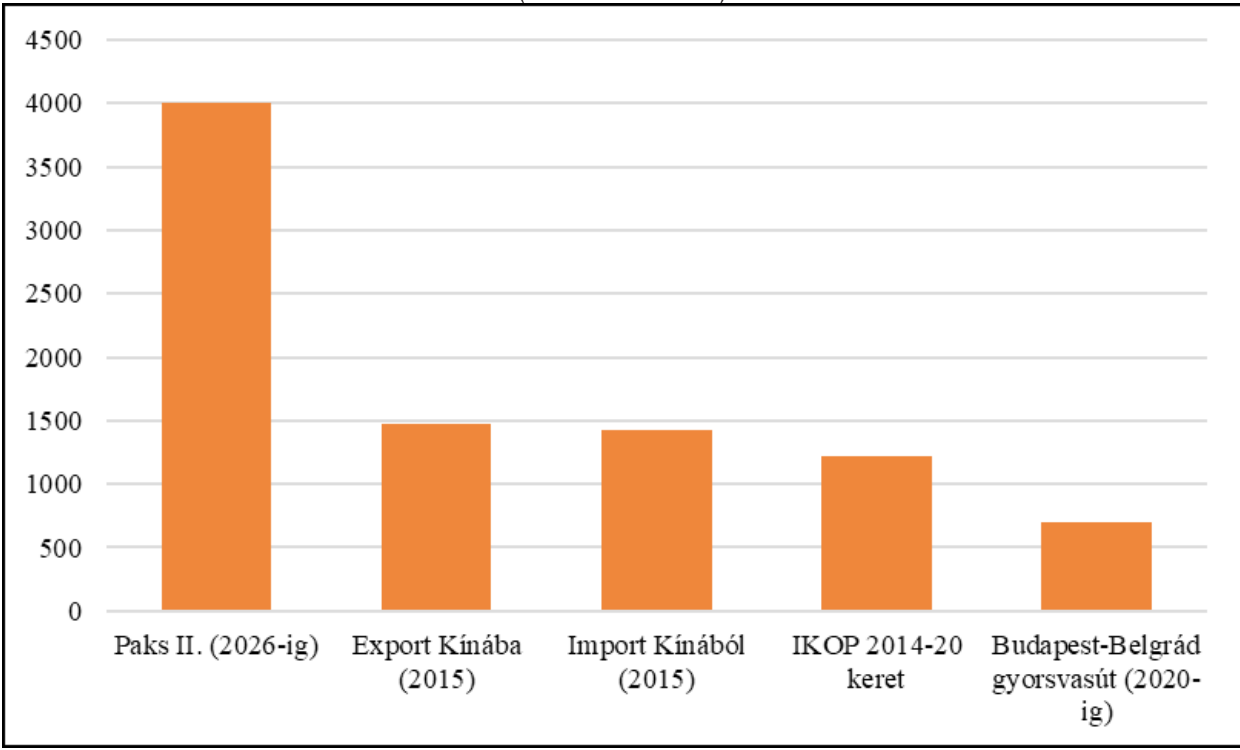

\section{Az Eurázsia-narrativa megvalósítása}

A magyar kormány szinte egyedülálló intenzitással látott neki a kommunikációban megjelenített Eurázsia-viszonyrendszer építésének. amely a külpolitikai és a külgazdasági mellett más politikákat és terüileteket is érint.

Kínával a külügyi találkozók a Magyarország méretéből adódónál sokkal magasabb, kormányzati szinten folytak és folynak: Orbán Viktor miniszterelnök vagy Szijjártó Péter külügyminiszter a főbb egyezteté sek során Hszi Csin-ping államfóvel, illetve a kínai külügyminiszterrel találkozik (Magyarország Kormánya, 2017; Magyarország Kormánya, 2019b). Hasonló a helyzet a másik eurázsiai nagyhatalom, Oroszor szág esetében is: Vlagyimir Putyin szinte évente látogat Budapestre.

6 Forrás: Kocsis, Komjáthỵ, Péti és Salamin, 2017. 264. o. 


\section{Külïgyi Szemle}

Az Új Selyemúthoz kapcsolódóan a magyar kormány aktív résztvevóje a 2011-ben éppen Budapesten bejelentett 16+1 együttmúködésnek, amelynek célja a kelet-közép-európai régió és Kína kapcsolatának az erősítése és a felek közötti kereskedelem bővitése. Ezt jelzi például, hogy Magyarország 2014 májusa óta ad otthont a Kína-Kelet-KözépEurópa Turisztikai Koordinációs Központnak (Tourism Coordination Centre, TCC), amelynek feladata, hogy az együttmúködésben részt vevő 17 országot egyetlen turisztikai célterületként népszerűsítse a kínai turisztikai piacon (Magyarország Nagykövelsége Peking, n. d., 1. o.). 2016-ban pedig a kelet-közép-európai régióban elsőként Buda pesten nyitott irodát a Kínai Nemzeti Turisztikai Hivatal, amely a kínai desztinációkat reklámozza Európában.

Az Eurázsia-narratíva megvalósításában a kormány mellett a magyar jegybank is szerepet vállal: 2016 óta egy külön szakterület feladata a keleti nyitás politikájának a támogatása, illetve a bank nemzetközi kapcsolatrendszerének a szélesítése és az ázsiai kapcsolatainak az erősítése (Magyar Nemzeti Bank, 2019). A Magyar Nemzeti Bank (MNB) - Kelet-Közép-Európa jegybankjai közül egyedüliként - devizacsere-megállapodást kötött a kínai jegybankkal (People’s Bank of China, POBC). A 2015-ben indított Jegybanki Renminbi Program és a Budapesti Renminbi Kezdeményezés a kínai deviza nemzetközi elszámolásokban játszott szerepének a növelését és Magyarország befektetési palettájának és finanszírozási forrásainak a bővítését egyaránt szolgálja (bóvebben ld. Erhart, 2015). 2018. november 9-10-én rendezték meg Budapesten az első 16+1 jegybankelnöki csúcstalálkozót Kína és a kelet-közép-európai országok részvételével, amelyet az MNB és a kínai jegybank közösen szervezett.

Mindezek mellett a legnagyobb kínai bankok közül a Bank of China Budapesten működteti az egyik fontos európai központját. Ez gazdasági és geoökonómiai szempontból azért előnyös, mert a bank úgy van jelen a magyar fővárosban, hogy sokszor az orosz ügyleteket is innen szervezi (Brückner, 2019). Továbbá a kommunikációs technológiai óriás, a Huawei legnagyobb európai gyártó- és logisztikai központja is Magyarországon székel. 
A keleti nyitási politika gazdasági hatásainak az értékelése nem tárgya a jelen dolgozatnak, ezért csupán néhány összefüggést eme lünk ki. A Magyarországra irányuló eurázsiai beruházások éves menynyisége és részesedése is egyenletesen emelkedett. Míg 2011-ben az 1 százalékot sem haladta meg, addig 2018-ban már elérte a 4,5 százalékot, a mennyisége pedig megháromszorozódott (4. ábra). Az emelke dő tendencia következtében 2019 első fél évében Németország helyett már Dél-Korea volt hazánkban a fỏ befektető (Magyarország Kormánya, 2019a). A kelet-közép-európai régió országai közül ide érkezik a legtöbb kínai tőkebefektetés: már 2010-ben elérte az összes térség belinek a 89 százalékát (Chen, 2012, 4. o.). 2014-re pedig a volume ne elérte az 556 millió amerikai dollárt, ami messze a legmagasabb érték a régióban (Szunomár, 2015, 5. o.). Mindez kiegészíti az Európai Unióból érkező befektetéseket, amelyek továbbra is körülbelül kéthar mados arányt képviselnek az összes Magyarországra érkező közvet lentőke-befektetésben.

A külkereskedelmi hatások beérését azonban még számos tényező nehezíti. Magyarország részéről azt a gazdasági célkitűzést, hogy az export nagyobb mennyiségben és arányban a keleti országokba irá nyuljon, a jelentékeny erőfeszítések ellenére még nem sikerüilt telje síteni. De ennek okai között van például az is, hogy az oroszországi kereskedelmet voltaképpen lefelezte a krími válságot követően beve zetett szankciós politika.

Geopolitikai és gyakorlati szempontból Magyarország a két legfőbb eurázsiai hatalommal (Oroszországgal és Kínával) történő partnerség kialakításában mindenképp néhány előnnyel rendelkezik a térségbeli versenytársakhoz képest. A posztszocialista uniós partnerek közül az együttmúködés iránt érdekelt lehetne Csehország, amely földrajzilag a legközelebb helyezkedik el a fejlett nyugat-európai gazdaságokhoz, azonban Prágában leginkább értékalapon ítélik meg a keleti rendsze reket, ezért a befektetések esetén számukra a Magyarország részérỏl tanúsított támogató politika kifizetődőbb (Buzna, 2019). Románia és különösen Lengyelország a méretéből adódóan jelentősebb ország, mint hazánk, azonban mindkettő erősebben atlantista irányultságú, 


\section{Külïgyi Szemle}

az Amerikai Egyesült Államok legfőbb térségbeli katonai szövetsé gesei, emellett „ruszofóbok” is. Románia adott esetben akár nyitott nak is mutatkozna a Kínával való együttműködésre, hiszen több nagy stratégiai beruházásról is történt megállapodás a két ország között. Ugyanakkor a cernavodăi atomerőmủ kínai bővítésérỏl szóló tárgya lások eljutottak ugyan a konkrét megállapodásig, az USA nyomására azonban elállt tőle az ország (Brînză, 2019).

\section{4. ábra ${ }^{7}$}

Az „eurázsiai” országokból érkező közvetlentőke-befektetések 2011 és 2018 között

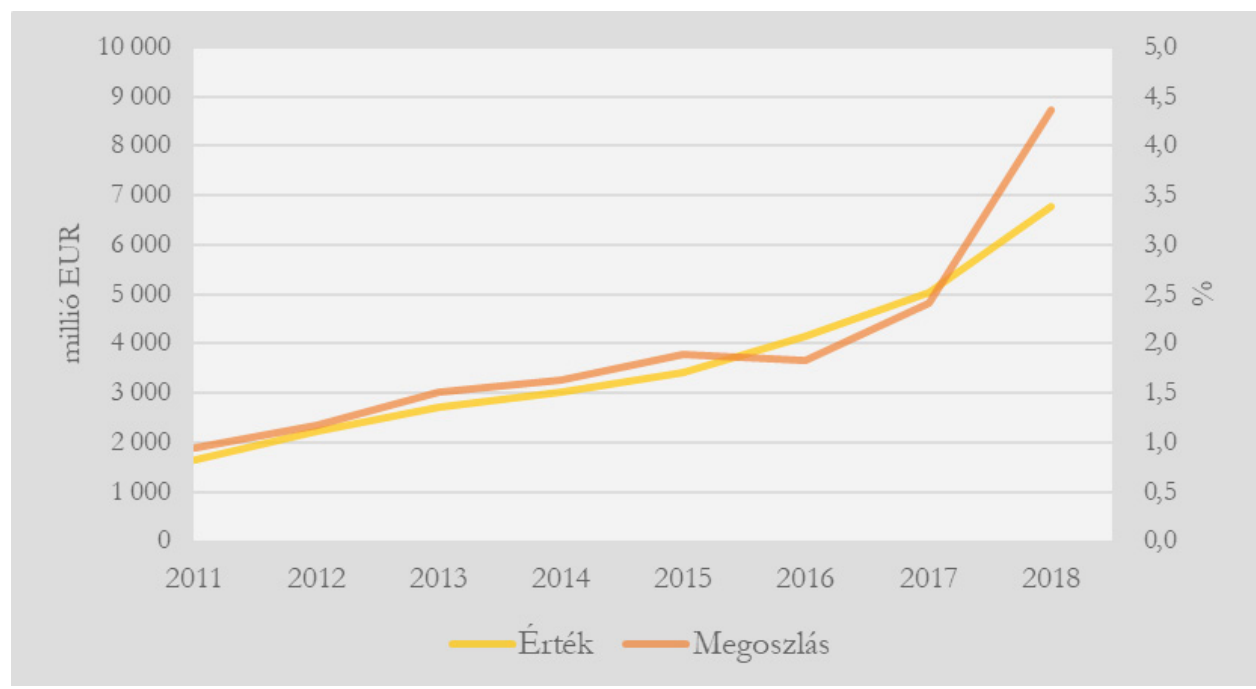

Az előnyöket a magyar kormányzat gesztusok és stratégiai beru házások révén kívánja elmélyíteni. 2015-ben Magyarország az első EU-tagállamként írta alá az Egy övezet, egy út nevet viselő stratégiát. 2017-ben csatlakozott a kínai kezdeményezésú Ázsiai Infrastrukturá lis Befektetési Bankhoz (Asian Infrastructure Investment Bank, AIIB), emellett kész megkezdeni a tárgyalásokat, hogy teljes jogú tagként csatlakozzon az Eurázsiai Fejlesztési Bankhoz (Eurasian Developmenı

7 Forrás: a Magyar Nemzeti Bank adatai alapján saját számítás és szerkesztés. 
Bank, EDB) is (Magyarorszag Kormánya, 2019c). Hazánk mindeze ken felül megfigyelői státusszal rendelkezik a Türk Tanácsban, amely egyes török nyelvű, iszlám kultúrájú országokat tömörítő, voltaképpen geopolitikai szervezet. A tanács 2019-ben nyitotta meg európai képviseletét Budapesten.

A stratégiai beruházásokra a két legjobb példa a nemzetgazda sági jelentőségú Paksi Atomerőmú orosz hitelből történő bővitése, a Roszatom kivitelezésében, valamint a már említett Budapest-Belgrádvasútvonal korszerüsítése kínai hitelből és kínai vállalatok bevonásával. Az utóbbinak a magyarországi szakasza Peking számára azért is különösen fontos, mert kínai vállalatok először építhetnének uniós tagállamban vasúti pályát, így azt referenciaként fel tudnák használni más európai infrastruktúra-fejlesztések esetén is (Eszterhai, 2016). (Az orosz és kínai finanszírozású beruházások érthetően ugyanakkor nem csekély belpolitikai vitát is eredményeznek, melyekre azonban tanulmányunk céljából adódóan nem tér ki.)

A társadalmi megítélését tekintve a keleti nyitás politikájának ugyancsak megvannak az alapjai. Magyarországot, különösen régiós összehasonlításban, továbbra is egyfajta erỏs Nyugat-barát attitûd jellemzi, amely egyrészt a nyugati országok és intézmények kedvezỏ értékelésében, másrészt egy erőteljes Nyugat felé fordulásban is megjelenik. 2017-ben a magyar választók közül csaknem nyolcszor annyian (39\%) gondolták, hogy az országnak inkább a Nyugathoz kell tartoznia, mint ahányan azt, hogy a Kelethez (5\%) (Krekó, 2018, 384. o.). Ugyanakkor a társadalom közel fele „köztes” álláspontot foglal el e kérdésben, ami jól mutatja, hogy a magyar közvéleményben továbbra is erős az ország önálló politikáját, ,hídszerepét” hangsúlyozó hagyomány.

\section{Következtetések}

A magyar Eurázsia-koncepció a kisállami pozíció 21. századi lehetőségeinek a felismerésén alapuló és az ország földrajzi helyzetére épitő nemzeti geopolitikai stratégiaként értékelhető. A fókuszában álló keleti 


\section{Külïgyi Szemle}

nyitás politikája azonban nem a nyugati kapcsolatrendszer leépítését, sokkal inkább külpolitikai és külgazdasági diverzifikációt jelent, illetve a Kelet és Nyugat közti kapcsolatok katalizálását, egyfajta kapuszerep ambicionálását. Az Eurázsiára vonatkozó magyar elképzelés földrajzilag képlékeny: a narratívában főleg a posztszovjet térség országai jelennek meg, a legtöbbször Oroszországot említve, ám a BRI meghirdetése óta egyre inkább Kína kerül a fókuszába. E formálódó politikai szándékok ma már a szakpolitikákban is kezdenek megjelenni, hiszen pl. az Övezet és Út Kezdeményezés és általában az eurázsiai dimenzió a magas szintű fejlesztéspolitikai tervdokumentumokban is mindinkább tetten érhetô. Ám az új selyemút mint fejlesztéspolitikai lehetőség - a benne rejlő potenciál ellenére - nem vert még széles körben gyökeret a területi és az ágazati fejlesztések tervezése során. A keleti nyitás azonban nemcsak retorikában és diplomáciai szinten jelenik meg, hanem számos kormányzati intézkedésben és gazdasági döntésben is. Magyarország az Eurázsia-narrativa valósággá tételé ben kifejezetten aktív, a kormányzat intenzív diplomáciával és straté giai jelentőségű üzletekkel törekszik a kapcsolatok elmélyítésére.

Mindent összevetve, Ó Tuathail (2002) négy részből álló módszertani megközelítése alapján a magyar kormányzat Eurázsianarratívája az l. táblázat szerint foglalható össze.

Kijelenthető, hogy a keleti nyitás politikáját és az egységes eurázsiai gazdasági térség megvalósulását végső soron a nagyhatalmi kapcsolatok és geopolitikai érdekek határozzák majd meg. Az atlanti erőtér és Oroszország ellenséges viszonyára épülő világpolitikai rendszer keretén belül a Nyugat a magyar kormány keleti nyitási politikáját egyszerűen úgy értelmezi, hogy hazánk egyre közelebb kerül Moszkvához, s így az euroatlanti integrációknak egyre kevésbé megbízható szövetségese. E megítélésben akkor következhetne be változás, ha az USA és Oroszország feszült viszonya enyhülne, s valamelyest csökkenne a két nagyhatalomnak az olykor már a hidegháborús időket idéző szembenállása. Annak ellenére, hogy Joe Biden személyében új elnök került a Fehér Házba, a kettejük kapesolatában jelentős javulás a közeljövőben nem várható. 


\section{1. táblázat}

A magyar kormány Eurázsia-narratívája

Ó Tauthail módszertana alapján

\begin{tabular}{|c|c|}
\hline $\begin{array}{l}\text { 1. Külpolitikai } \\
\text { probléma }\end{array}$ & $\begin{array}{l}\text { Új világrend, } \\
\text { átalakulóban lévő erőviszonyok, } \\
\text { Európa veszít a jelentóségébobl, } \\
\text { az uniós piacok stagnálása } \\
\end{array}$ \\
\hline $\begin{array}{l}\text { 2. Geopolitikai } \\
\text { stratégia }\end{array}$ & $\begin{array}{l}\text { Eurázsiai léptékủ együttmúködés } \\
\text { Nyugat-Európa és a Kelet között, } \\
\text { "Lisszabontól Vlagyivosztokig tartó } \\
\text { szabadkereskedelmi övezet", } \\
\text { a magyar kivitel diverzifikációja }\end{array}$ \\
\hline $\begin{array}{l}\text { 3. A stratégia } \\
\text { finomhangolása, } \\
\text { akkomodációja }\end{array}$ & $\begin{array}{l}\text { Keleti nyitás politikája: } \\
\text { „Magyarország kapu } \\
\text { a kelet-nyugati viszonyban”, } \\
\text { „ïzletelés helyett } \\
\text { valódi keleti nyitásra törekszik” }\end{array}$ \\
\hline $\begin{array}{l}\text { 4. A probléma lezárása, } \\
\text { konkrét lépések }\end{array}$ & $\begin{array}{l}\text { Stratégiai partnerség Eurázsia országaival, } \\
\text { stratégiai projektek indítása } \\
\text { és intenzív diplomáciai aktivitás, } \\
\text { a hídtérségi szerepkör megteremtése } \\
\text { elkezdődött }\end{array}$ \\
\hline
\end{tabular}

A többpólusú világ formálódásának az alapvető kérdése, hogy ki alakul-e egy új, 21. századi eurázsiai kontinens. Ennek a kulcsa egyértelmúen az, hogy milyen lesz a gazdasági és a politikai szövetség Oroszország és Kína között. Moszkva és Peking kapcsolata jelenleg csak egyes ügyek mentén szerveződő érdekszövetségnek tekinthető, s nem közös értékeken alapul (Buchanan, 2020).

A világpolitikai egyensúly egyik kulcsa a stabil euroatlanti szövet ség, az USA és az európai államok, a NATO és az EU erős szövetsége. Jelenleg az látható, hogy az Európai Unió egyes globális gazdasági hatalmi törekvései és leginkább a dollár globális egyeduralmát kihívó euró „projektje” ver éket az európai-amerikai viszonyrendszerben (Matolesy, 2019, 18. о.). 


\section{Külïgyi Szemle}

„Az Egyesült Államok és Németország erős szövetségesi kapcso lata stabilizáló erő lehetne az egész európai kontinensre nézve, s így közvetve hazánk külügyi kapcsolatait is megerősítené, a keleti államok felé is.

Az európai kontinens és a formálódó eurázsiai erőtér egészé nek alapvető kérdése Berlin és Moszkva kapcsolatrendszere... Az erősödő gazdasági kapcsolatokra, s nem a politikai szembenállásra épülő német-orosz szövetség az egyik legfontosabb alapja lehetne a keleti nyitási politikánk sikerének.

Az eurázsiai erôtér formálódása azonban már túllép a németorosz tengelyen, és sokkal inkább egy új német-orosz-kínai tengely kialakulásához köthető. Ezért alapvető kérdés, hogy milyen lesz Németország és Kína kapcsolata, s annak következtében az EU Kína-politikája.

Ugyanakkor a legfontosabb kérdések közé tartozik az is, hogy milyen lesz az Egyesült Államok és Kína kapcsolata” (Bernek, 2018a, 140-141. o.).

Joe Biden megválasztása ellenére sem igazán várható jelentős enyhülés a két ország viszonyában, hiszen Kína az USA vezette nemzetközi intézményrendszerrel szemben egyre inkább kihívóként lép fel. Magyarország számára Washington és Peking kapcsolatának a rendeződése „kedvező lenne, hiszen stabil nagyhatalmi hátteret biz tosítana a Dél-, Kelet- és Délkelet-Ázsia országai felé történő nyitásunkhoz" (Bernek, 2018a, 141. o.).

A felsorolt kapcsolatok alakulása jelentős mértékben befolyásolhatja egy olyan kisállam Eurázsia-politikájának a sikerességét, mint Magyarország. Mindenesetre a jelenlegi állás szerint a nagyhatalmak viszonya olykor olyan mértékben feszuilt, hogy már-már a korábbi hidegháborús állapotokat idézi. 


\section{Irodalomjegyzék}

Belügyminiszlérium Vizügyi Fóigazgalóság (2017). Nemzeti Vízstratégia (Kvassay Jenó Terv). A letöltés ideje: 2021. január 10. https://www. vizugy.hu/vizstrategia/documents/997966DE-9F6F-4624-91C53336153778D9/Nemzeti-Vizstrategia.pdf.

Benyhe István (2018). Magyarország helyzete és ami abból következik 1. rész. Magyar Szemle, 23(9-10) 23-30. A letöltés ideje: 2021. február 22. http://www.magvarszemle.hu/cikk/20181019 magvarorszag helvzetees ami abbol kovetkezik.

Bernek Ágnes (2018a). Hazánk keleti nyitás politikája és a 21. századi geopolitikai stratégiák összefüggései. Külügyi Szemle, 17(2), 122-144.

Bernek Ágnes (2018b). Kelet-Közép-Európai Geopolitikai Tanulmány. A közép és kelel európai országok a 21. században löbbpólusú világban. A 20. század Nyugat és Kelel közölti ütközózónájától a 21. századi eurázsiai hidıérségig. Budapest: Pallas Athéné Innovációs és Geopolitikai Alapítvány.

Bod Péter Á kos (1995). Sokkterápia vagy fokozatosság: a magyar piacgazdaság átalakulásának tanulságai: 1. Magyar Szemle, 4(10) 1011-1026. A letöltés ideje február 22. http:/www.magyarszemle.hu/cikk/sokkterapia_vagy fokozatossag_a_magyar_piacgazdasag_atalakulasanak_tanulsagai_1_ resz.

Bod Péter Ákos (2019). A magyar gazdaságpolitika 1989 és 2019 között. Gazdaság és Pénzügy, 6(1), 16-38.

Brînză, Andrea (2019). How the US-China Competition Is Playing Out in Romania. The Diplomat. A letöltés ideje: 2020. augusztus 29. https:// thediplomat.com $/ 2019 / 11 /$ how-the-us-china-competition-is-plavingout-in-romania/.

Brückner Gergely (2019). Borzasztó nehéz a keleti nyitás. Index.hu A letöltés ideje: 2020. augusztus 29. https://index.hu/gazdasag/2019/01/08/ kereskedni_kinaval_-avagy miert olvan_borzaszto_nehez_a keleti nyitas.

Buchanan, Elizabeth (2020). There's No (New) China-Russia Alliance. ASPI. A letöltés ideje: 2020. augusztus 29. https://www.aspistrategist.org.au/ theres-no-new-china-russia-alliance/.

Buzna Viktor (2019). Érdekvezérelt magyar Kína-stratégia. Magyar Nemzel A letöltés ideje: 2020. augusztus 29. https://magyarnemzet.hu/kulfold/ erdekvezerelt-magyar-kina-strategia-6142880/. 


\section{Külïgyi Szemle}

Calder, Kent E. (2019). Super Continent: The Logic of Eurasian Integration. Stanford: Stanford University Press.

Chen, Xin (2012). Trade and Economic Cooperation Between China and CEE Countries. Instilute of European Studies, Chinese Academy of Social Sciences, Working Paper Series on European Studies, 6(2).

Emberi Erốforrások Miniszlériuma (2014). Tudománypolitikai Stratégia (2014-2020). A letöltés ideje: 2020. augusztus 29. http://20102014. kormany.hu/download/2/4f/fo000/2013\%2009\%2012\%20 Tudomanypolitikai\%20Strategia\%20honlapra.pdf.

Erhart Szilárd (2015). A jegybanki Renminbi program stratégiai keretei a nemzetközi gyakorlat fényében. Magyar Nemzeli Bank. A letöltés ideje: 2020. augusztus 29. https://www.mnb.hu/letoltes/erhart-szilarda-jegybanki-renminbi-program-strategiai-keretei-a-nemzetkozigvakorlat-fenveben.pdf.

Eszterhai Viktor (2016). Kelet-Közép Európa és Magyarország helye a Selyemúton. PAGEO Kulatóintézel. A letöltés ideje: 2020. augusztus

29. http://www.geopolitika.hu/hu/2016/11/24/kelet-kozep-europa-esmagyarorszag-helve-a-selvemuton/.

Frankopan, Peter (2019). The New Silk Roads: The Present and Future of the World. London: Bloomsbury.

Horkay Nándor, Péti Márton és Sütő Attila (2015). Kárpát-haza Fejlesztési Koncepció 2030. In Bali János el al. (szerk.), NSKI Annales 2014 (9-18. o.) Khanna, Parrag (2019). The Future is Asian. New York: Simon \& Schuster.

Kocsis János Balázs, Komjáthy Dénes és Péti Márton (2017). Kína Új Selyemút kezdeményezésének bemutatása és nemzetközi értelmezései.

In Péti Márton és Jeney László (szerk.), Az Új Selyemúl Gazdasági Övezel geostralégiai és földrajzi dimenziói (13-36. o.)

Kocsis János Balázs, Komjáthy Dénes, Péti Márton és Salamin Géza (2017).

Az Új Selyemút, mint fejlesztéspolitikai tényező. In Péti Márton és Jeney László (szerk.), Az Új Selyemút Gazdasági Övezel geostratégiai és földrajzi dimenziói (249-283. o.)

Központi Statisztikai Hivatal (2010). Magyarország 1989-2009 A változások lükrében. Budapest: Központi Statisztikai Hivatal.

Krekó Péter (2018). Oroszország a magyar közvéleményben. In Kolosi Tamás és Tóth István György (szerk.), Társadalmi Riport 2018. (382-396. o.)

Maçães, Bruno (2018). Bell and Road: A Chinese World Order. London: Hurst \& Company. 
Magyar Közlöny (2014). 1/2014. (I. 3.) OGY határozat. A Nemzeti Fejlesztés 2030 - Országos Fejlesztési és Területfejlesztési Koncepcióról. Január 3. 7-298. o. A letöltés ideje: 2021. szeptember 20. http://www.kozlonvok. hu/nkonline/index.php?menuindex=200\&pageindex=kozltart\&ev=2014 \& szam $=1$.

Magyar Nemzeli Bank (2018). Növekedési jelentés 2018. A letöltés ideje: 2020. augusztus 29. https://www.mnb.hu/letoltes/novekedesi-jelentes2018-digitalis.pdf.

Magyar Nemzeli Bank (2019). Az MNB keleti kapcsolatai. A letöltés ideje: 2020. október 29. https://www.mnb.hu/a-jegybank/informaciok-ajegybankrol/nemzetkozi-kapcsolatok/az-mnb-keleti-kapcsolatai.

Magyarország Kormánya (2012). Széll Kálmán terv 2.0. A letöltés ideje: 2020. augusztus 29. https://2010-2014.kormany.hu/download/3/e8/80000/1A k \%C3\%B6vetkez $\%$ C5\%91 1\%C3\%A9p \%C3\%A9s\%20\%28SzKT $\% 20$ 20\%29.pdf.

Magyarország Kormánya (2017). Orbán Viktor Pekingben. A letöltés ideje: 2020. október 29. https:/www.kormanv.hu/hu/a-miniszterelnok/fotok/ orban-viktor-pekingben.

Magyarország Kormánya (2019a). Magyarország érdeke, hogy Kelet és Nyugat szorosan együttmúködjön. A letöltés ideje: 2020. augusztus 29. https://2015-2019.kormanv.hu/hu/kulgazdasagi-es-kulugvminiszterium/ hirek/magvarorszag-erdeke-hogy-kelet-es-nyugat-szorosanegvuttmukodjon.

Magyarország Kormánya (2019b). Orbán Viktor a kínai államfóvel tárgyalt. A letöltés ideje: 2020. október 29. https://www.kormany.hu/hu/aminiszterelnok/hirek/orban-viktor-a-kinai-allamfovel-targvalt.

Magyarország Kormánya (2019c). Újabb fejlesztési bankhoz csatlakozhat Magyarország (2019). A letöltés ideje: 2020. október 29. https://2015-2019. kormanv.hu/hu/nemzetgazdasagi-miniszterium/hirek/ujabbfejlesztesi-bankhoz-csatlakozhat-magyarorszag.

Magyarország Kormánya (n. d.) Főoldal. A letöltés ideje: 2020. augusztus 29. https:/www.kormanv.hu/hu.

Magyarország Nagykövelsége Peking (n. d.). Kína-Közép-Kelet-Európa Turisztikai Koordinációs Központ. A letöltés ideje: 2020. november 29. https://peking.mfa.gov.hu/page/kina-koezep-kelet-europa-turisztikaikoordinacios-koezpont.

Matolesy György (2019). The American Empire vs. the European Dream. The Faliure of the Euro. Budapest: Pallas Athéné Publishing House. 


\section{Külïgyi Szemle}

Matura Tamás (2012). A magyar-kínai kapcsolatok elmúlt két éve. Külügyi Szemle, 11(2), 9-23.

Matura Tamás (2016). Hungary: Along the New Silk Road across Central Europe. In van der Putten, Frans-Paul, Seaman, John, Houtari, Mikko, Ekman, Alice és Otero-Iglesias, Miguel (szerk.), Europa and China's New Silk Roads (35-37. o.)

Miklós Gábor (2013). A magyar eladósodás és a válság hatásai (Hungarian Indebtedness and Its Effects). Köz-gazdaság, $8(1), 77-86$.

Miniszterelnök.hu (2018). A letöltés ideje: 2020. október 29. https:// miniszterelnok.hu/orban-viktor-beszede-a-kinai-es-kelet-kozepeuropai-orszagok-jegybankelnokeinek-talalkozojan/

Nagy Miklós Mihály (2014). Veszélyzóna, avagy Geopolitikai Puffer? Köztes Európa történeti, Politikai földrajzi kérdései. Közles-Európa, 6(1), 29-38.

Nemzelgazdasági Miniszlérium (2011). Külgazdasági Stratégia Szakmai vitairat, 2011. május. Pestmegye.hu A letöltés ideje: 2021. január 10. http:// www.pestmegye.hu/images/2014/agazati_strategiak/Kulgazdasagi Strategia_2011.pdf.

Nemzelgazdasági Miniszlérium (2012). Wekerle Terv. A magyar gazdaság Kárpát-medencei léptékủ növekedési stratégiája. A letöltés ideje: 2020. augusztus 29. https://www.nth.gov.hu/hu/media/download/261.

Nemzelgazdasági Miniszlérium (2017). Nemzeti Turizmusfejlesztési Koncepció. Erôt adó Magyarország. A versenyképes turizmus koncepciója 2014-2024. A letöltés ideje: 2021. január 29. https://mtu. gov.hu/documents/prod/mtu_strategia_2030.pdf.

Nemzeli Fejleszlési Miniszlérium (2012). Nemzeti energiastratégia 2030.

A letöltés ideje: 2021. január 29. https://2010-2014.kormany.hu/ download/4/f8/70000/Nemzeti\%20Energiastrat\%C3\%A9gia\%20 2030\%20teljes\%20v\%C3\%Alltozat.pdf.

Nemzeli Fejleszlési Miniszlérium (2014). Nemzeti Közlekedési Infrastruktúra-fejlesztési Stratégia. A letöltés ideje: 2020. augusztus 29. http:/www.kormany.hu/download/b/84/10000/ Nemzeti $\% 20 \mathrm{~K} \% \mathrm{C} 3 \%$ B6zleked\%C3\%A9si\%20Infrastrukt $\%$ C3\%BArafejleszt\%C3\%A9si\%20Strat\%C3\%A9gia.pdf.

Nemzeli Fejleszlési Miniszlérium (2015). Második Nemzeti Éghajlatváltozási Stratégia 2014-2025 kitekintéssel 2050-re. 
A letöltés ideje: 2020. augusztus 29. http://20102014.kormanv. hu/download/7/ac/01000/M\%C3\%A1sodik\%20Nemzeti\%20 \%C3\%89ghajlatv\%C3\%Alltoz\%C3\%A1si\%20Strat\%C3\%A9gia\%2020142025\%20kitekint\%C3\%A9ssel\%202050-re\%20-\%20szakpolitikai\%20 vitaanvag.pdf.

Ó Tuathail, Gearóid (2002). Theorizing Practical Geopolitical Reasoning: The Case of the United States' Response to the War in Bosnia. Political Geography, 21(5), 601-628.

Oblath Gábor (2014). Gazdasági átalakulás, nekilendülés és elakadás. Magyarország makrogazdasági konvergenciája az Európai Unió fejlett térségéhez az 1990-es évek elejétől 2013-ig. In Kolosi Tamás és Tóth István György (szerk.), Társadalmi Riport (21-50. o.)

Péti Márton (2010). A területi tervezés és féjleszlés a fenntarthatóság jegyében \& stratégiai környezeli vizsgálatok földrajzi szemlélellel. Szeged: JATEPress Kiadó.

Péti Márton (2014). Magyarország Partnerségi Megállapodása 2014-2020. A területfejlesztés és gazdaságfejlesztés megújításának újabb lépése. Falu Város Régió, (2), 12-22.

Péti Márton, Botka Mónika, Szilágyi Györgyi, Salamin Géza és Radvánszki Ádám (2009). Kézikönyv a területi kohézióról. Területi megközelítés alkalmazása a közszféra által támogatott fejlesztésekben. Budapest: Nemzeti Fejlesztési és Gazdasági Minisztérium.

Salamin Géza (2015). Transforming Regional Position of Central-Eastern Europe in the Economic Space of the European Union with Special Reference to Hungary. Hungarian Sludies, 29(1-2), 73-91.

Szunomár Ágnes (2015). Blowing from the East. International Issues \& Slovak Foreign Policy Affairs, 24(3).

Vidékfejleszlési Miniszlérium (2013). Nemzeti Vízstratégia A letöltés ideje: 2021. január 10. http://www.mernokkamara-gyor.hu/uploads/files/2013/ Nemzeti_V_zstrat_gia.pdf. 